\title{
Prenatal diagnosis of auriculocondylar syndrome with a novel missense variant of GNAI3: a case report
}

\author{
Xiaoliang Liu', Wei Sun², Jun Wang ${ }^{3}$, Guoming Chu', Rong He', Bijun Zhang ${ }^{1}$ and Yanyan Zhao ${ }^{1 *}$ (i)
}

\begin{abstract}
Background: Auriculocondylar syndrome (ACS) is a rare disorder characterized by micrognathia, mandibular condyle hypoplasia, and auricular abnormalities. Only 6 pathogenic variants of GNAI3 have been identified associated with ACS so far. Here, we report a case of prenatal genetic diagnosis of ACS carrying a novel GNAI3 variant.

Case presentation: A woman with 30 weeks of gestation was referred to genetic counseling for polyhydramnios and fetal craniofacial anomaly. Severe micrognathia and mandibular hypoplasia were identified on ultrasonography. The mandibular length was $2.4 \mathrm{~cm}$, which was markedly smaller than the 95th percentile. The ears were low-set with no cleft or notching between the lobe and helix. The face was round with prominent cheeks. Whole-exome sequencing identified a novel de novo missense variant of c.140G > A in the GNA/3 gene. This mutation caused an amino acid substitution of p.Ser47Asn in the highly conserved G1 motif, which was predicted to impair the guanine nucleotidebinding function. All ACS cases with GNAI3 mutations were literature reviewed, revealing female-dominated severe cases and right-side-prone deformities.
\end{abstract}

Conclusion: Severe micrognathia and mandibular hypoplasia accompanied by polyhydramnios are prenatal indicators of ACS. We expanded the mutation spectrum of GNAI3 and summarized clinical features to promote awareness of ACS.

Keywords: Auriculocondylar syndrome, GNAI3, Craniofacial deformity, Prenatal diagnosis, Case report

\section{Background}

Auriculocondylar syndrome (ACS, MIM\#602483, \#614669 and \#615706) is an extremely rare monogenic condition affecting neural crest cell development within the first and second pharyngeal arches [1]. It is characterized by craniofacial malformations with a triad of core features: micrognathia, mandibular condyle hypoplasia, as well as a distinctive question mark ear (QME) with a cleft or notching between the lower helix and the lobule. Other features, including microstomia, palatal

\footnotetext{
*Correspondence: yyzhao@sj-hospital.org

${ }^{1}$ Department of Clinical Genetics, Shengjing Hospital of China Medical University, Shenyang, China

Full list of author information is available at the end of the article
}

abnormalities, glossoptosis, respiratory distress, round face with prominent cheeks, facial asymmetry, hearing loss, and postauricular tags, may be manifested [2]. Marked inter- and intra-familial phenotypic variability and incomplete penetrance have been observed in ACS $[3,4]$. Genetic variants underlying ACS have been identified in three genes: guanine nucleotide binding protein alpha-inhibiting activity polypeptide 3 (GNAI3), phospholipase C beta 4 (PLCB4), and endothelin 1 (EDN1), all of which are implicated in the EDN1-endothelin type A receptor (EDNRA) pathway [2, 5]. Gai3, encoded by the GNAI3 gene, is a member of the heterotrimeric G proteins. It has five guanine nucleotide-binding sites of G1-G5 boxes in the guanosine triphosphate catalytic domain [6]. So far, only 6 mutations of GNAI3 have been 


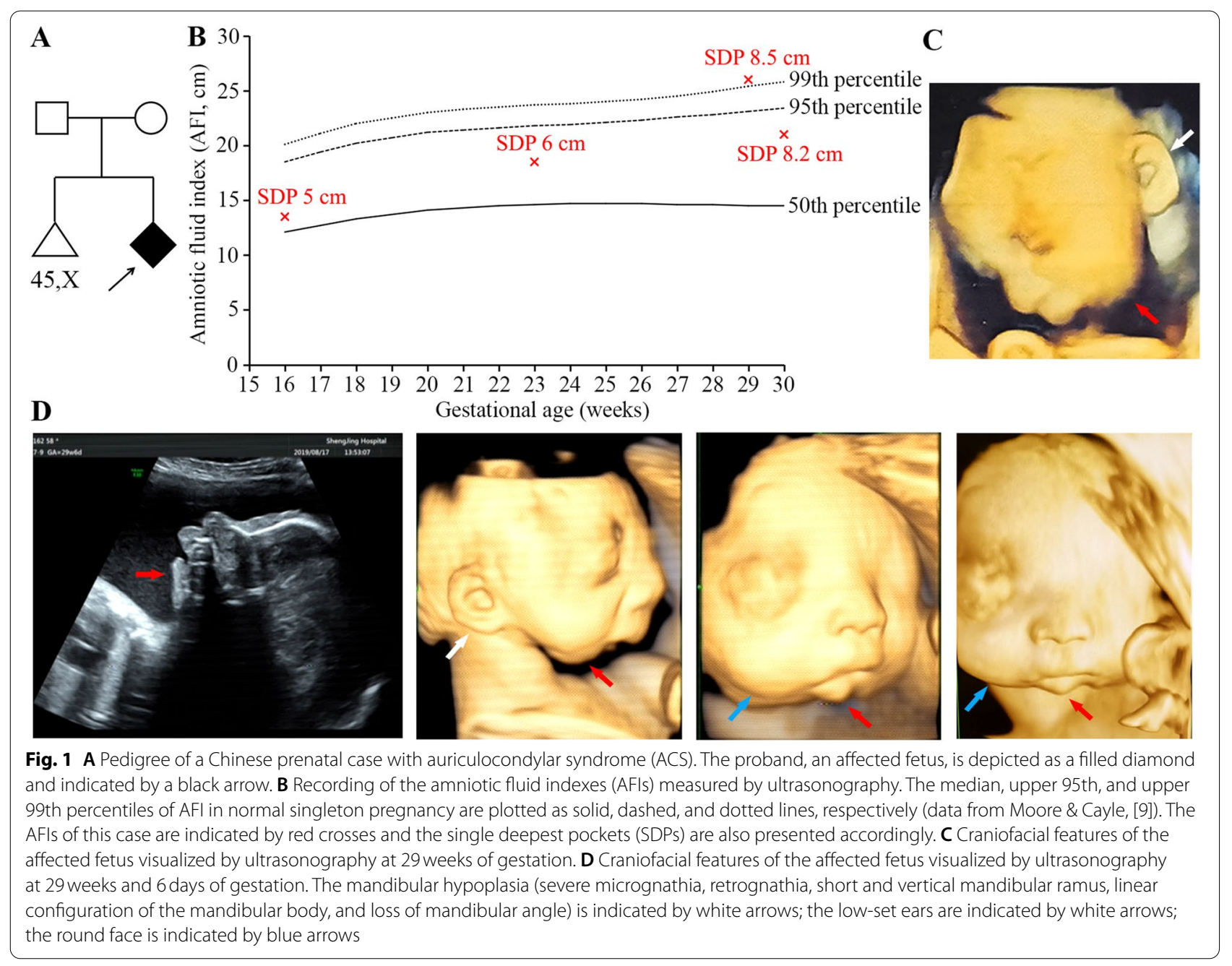

identified in autosomal dominant type I ACS, all of which affected the conserved amino acid positions that cluster within the nucleotide binding pocket $[3,4,7,8]$.

In the present study, we report a prenatal genetic diagnosis case of ACS in the Chinese population. A novel missense variant of GNAI3 was identified in the G1 box, which was predicted to impair the guanine nucleotidebinding function. The clinical features of all ACS cases with GNAI3 mutations described in the literature were reviewed.

\section{Case presentation}

A 27-year-old gravida 2, para 0 Chinese woman (body weight: $62 \mathrm{~kg}$, height: $162 \mathrm{~cm}$ ) was referred to genetic counselling at 30 weeks of gestation due to polyhydramnios and fetal craniofacial deformities. She had experienced first-trimester spontaneous pregnancy loss of a 45 , $\mathrm{X}$ embryo. She denied consanguineous marriage to her 28-year-old husband, or any exposure to teratogens.
The couple showed no facial abnormalities, facial asymmetry, or micrognathia (Fig. 1A).

Routine antenatal examinations of this pregnancy were performed at her local county hospital, and maternal hyperthyroidism was diagnosed and treated with regular drugs since 10 weeks of gestation. Ultrasonography has been made at $8,12,16,23$ and 29 weeks of gestation. Attention was drawn by the continuously high amniotic fluid volume since 16 weeks, especially by the amniotic fluid index (AFI) of $25 \mathrm{~cm}$ and single deepest pocket (SDP) of $8.5 \mathrm{~cm}$ at 29 weeks to diagnose polyhydramnios (Fig. 1B) [9]. Micrognathia was not recognizable in the printed reports from the local hospital until 29 gestational weeks. The left ear was low-set with no cleft or notching between the helix and the lobule (Fig. 1C). The fetus was pinpointed for mandibular hypoplasia at our hospital by fetal anomaly scan at 29 weeks and 6 days of gestation (Fig. 1D), showing severe micrognathia, retrognathia, short and vertical mandibular ramus, linear configuration of the mandibular body, and loss of mandibular 
angle. The mandibular length was $2.4 \mathrm{~cm}$, which was markedly smaller than that of normal singleton fetuses at 29 weeks of gestation (median: $4.08 \mathrm{~cm}$; lower 95th percentile: $3.8 \mathrm{~cm}$ ) [10]. The right ear was low-set and semicircular in shape, with no cleft or notching. The face was round with prominent cheeks. No facial asymmetry was observed. The SDP and AFI was 8.2 and $21 \mathrm{~cm}$, respectively. The fetal stomach bubble was $2.78 \mathrm{~cm} \times 0.96 \mathrm{~cm}$, which was comparable to the normal gastric size of $28-30$ weeks gestational age $(2.23 \pm 1.54 \mathrm{~cm} \times 1.28 \pm 1.4$ $4 \mathrm{~cm}$ ) [11]. No other structural anomalies were found in the fetus.

Amniocentesis was performed to seek for potential genetic defects in the fetus. Chromosomal aneuploidy and rearrangement were excluded by low-coverage massively parallel CNV-sequencing, which yielded normal results (data not shown). A heterozygous variant of c.140G > A (NM_0064) was found in exon 2 of the GNAI3 gene by whole exome sequencing (WES, Fig. 2A). Further Sanger sequencing confirmed the variant to be de novo that it did not occur in the parents (Fig. 2B). It was a missense mutation that caused amino acid substitution of p.Ser47Asn. The Ser47 of Gai3 is highly conserved across various species (assayed by Ugene, Fig. 2C). Four in silico tools of PolyPhen, MutationTaster, PROVEAN, and SIFT were used to predict the harmfulness of this missense variant, showing all deleterious except for "Neutral" by PROVEAN (Fig. 2D). The Ser47 resided in the last amino acid of the G1 box. The 3D molecular model was built using SWISS-MODEL, and the H-bonds toward guanosine diphosphate (GDP) were calculated by Swiss-PdbViewer. As shown in Fig. 2E, the substitution of Ser47 to Asn 47 changed the sidechain direction and disrupted one of the three H-bonds to GDP, which might interfere with the binding and downstream signaling of the G protein. The variant was novel that has been neither reported in literature nor found in the public or inhouse database. This represents the seventh variant to the GNAI3 mutation spectrum in ACS, which was schematically depicted in Fig. 2F.

By reviewing literature, 19 individuals have been identified carrying 7 distinct missense variants from 8 cases, among which 4 were familial and 4 were sporadic (Table 1) [3, 4, 7, 8, 12-15]. Two individuals with GNAI3 mutations (p.Gly40Arg and p.Asn269Tyr) were normal and the penetrance of the GNAI3-underlying ACS was $89.4 \%(17 / 19)$. Being autosomal dominant, the number of female and male individuals carrying mutations were mostly equal (10:9). However, the ratio of female to male probands, who were usually the most severe in the family, was 6:2. Moreover, nearly all the individuals with tracheostomy $(7 / 8,87.5 \%)$ and gastrostomy $(7 / 7$, $100 \%)$ were females, indicating female-dominated severe cases. The overall expressivity of clinical characters was summarized, showing common features of micrognathia (78.95\%), auricular malformation (68.42\%), microstomia (66.67\%), prominent cheeks (63.16\%), mandibular hypoplasia $(57.89 \%)$, and round faces $(57.89 \%)$. Four patients showed asymmetric mandibular and auricular malformations that were either more severe on the right or right ear affected only, indicating right-side-prone deformities. The prenatal findings of two patients were retrospectively described in brief. Together with ours, all the three showed polyhydramnios (100\%), and two were noticed for micrognathia (66.67\%) in the ultrasonography.

The couple in the present case were informed of the genetic diagnosis of ACS, the details of this rare syndrome, and the recurrent risk in their future pregnancies. They eventually opted for pregnancy termination at the local hospital at 33 weeks and 6 days of gestation and refused any photography and post-mortem autopsy of the fetus.

\section{Discussion and conclusion}

ACS is an extremely rare disorder that was first described in 1998, first mapped a locus to 1p21.1-q23.3 in 2008, and first identified for causative genes in 2012 [7, 15, 16]. The rarity limits our understanding of the disease, especially with regard to the prenatal features of the disorder. In the present singleton fetus, the amniotic fluid volume had been high since 16 weeks of gestation, and met the criteria of polyhydramnios at 29 weeks. Prenatal ultrasound diagnosis of micrognathia has been reported as early as first trimester by experienced examiner [17]. In the present case however, micrognathia was overlooked in the local hospital from the nonstandard sections in printed reports at early gestational weeks. To improve detection of micrognathia, it is important to take the mid-sagittal plane of fetal facial profile. Objective assessments are required for less severe fetal micrognathia, including direct measurement of mandible length or indirect evaluation from angles of facial profiles such as inferior facial angle (IFA), facial maxillary angle (FMA), frontal nasomental angle (FNMA), and fetal profile line (FPL) [18]. Micrognathia and mandibular hypoplasia were confirmed in our hospital in the fetal anomaly scan from the homeotic transformed maxillary-like structures including short and vertical mandibular ramus, linear configuration of the mandibular body, and loss of mandibular angle. Two previous reports have mentioned about the prenatal ultrasonic findings of ACS, showing polyhydramnios in both and micrognathia in one fetus whose affected mother aroused early attention at 19 weeks of gestation $[12,14]$. The polyhydramnios was secondary to inefficient swallowing of amniotic fluid, which arose from temporomandibular joint ankylosis, microstomia, 


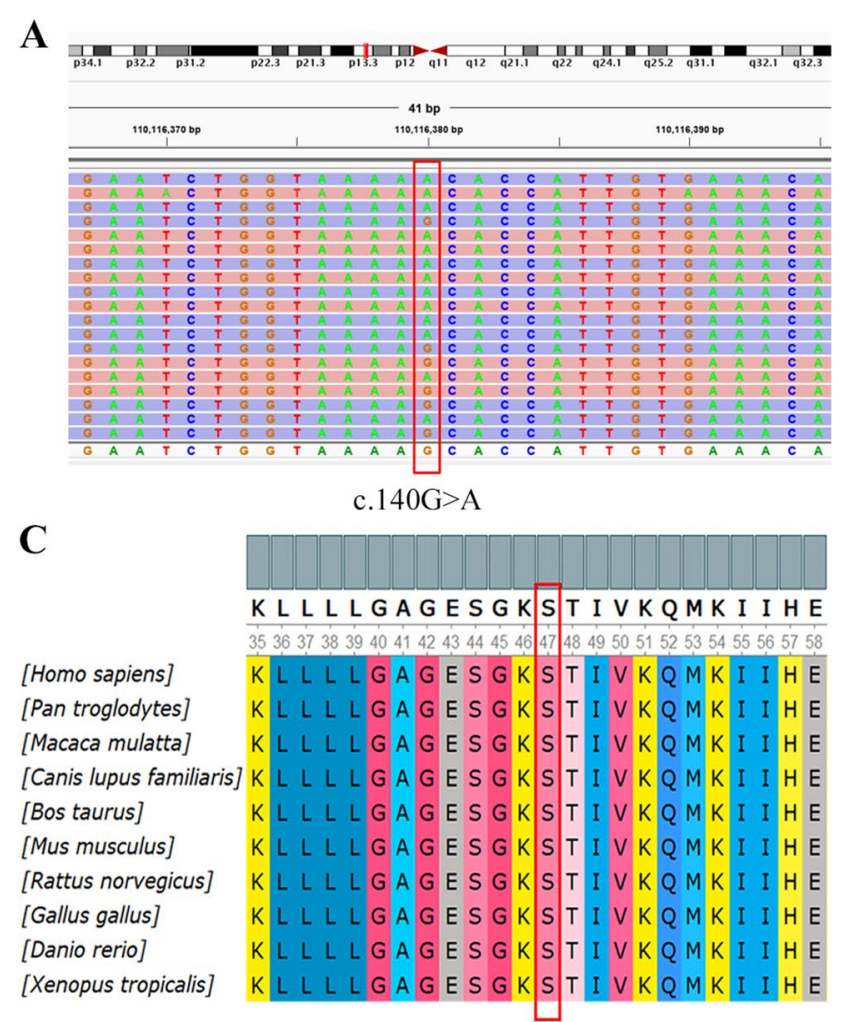

B

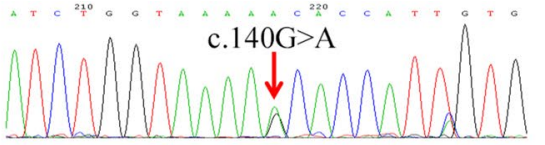

Father:

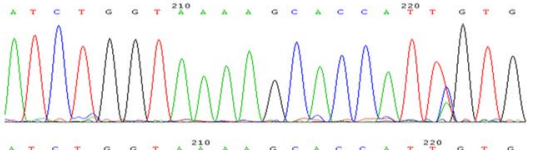

Mother:

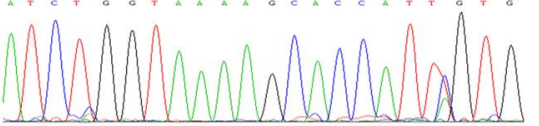

D PolyPhen-2 report for P08754 S47N

This mutation is predicted to be PROBABLY DAMAGING

with a score of 0.996 (sensitivity: 0.55 ; specificity: 0.98 )

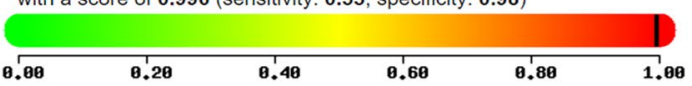

\section{mutation t@sting Prediction}

disease causing Model: simple_aae, prob: 0.999999999998727

\begin{tabular}{|c|c|c|c|c|c|c|c|c|}
\hline \multicolumn{9}{|c|}{ PROVEAN PREDICTION } \\
\hline POS & $\begin{array}{l}\text { RESIDUE } \\
\text { REF }\end{array}$ & $\begin{array}{l}\text { RESIDU } \\
\text { ALT }\end{array}$ & \begin{tabular}{|l|l|} 
S SCORE \\
\end{tabular} & \begin{tabular}{|l}
$\begin{array}{l}\text { PRE } \\
\text { (cutc }\end{array}$ \\
\end{tabular} & $\begin{array}{l}\text { DICTION } \\
\text { Iff }=-2.5) \\
\end{array}$ & \#SEQ & & LUSTER \\
\hline 47 & $\mathrm{~s}$ & & -2.38 & & Neutral & 581 & & 30 \\
\hline \multicolumn{6}{|c|}{ SIFT PREDICTION } & \multicolumn{3}{|c|}{ ANNOTATION } \\
\hline SCORE & \multicolumn{2}{|c|}{$\begin{array}{r}\text { PREDICTION } \\
\text { (cutoff }=0.05 \text { ) }\end{array}$} & \multicolumn{2}{|c|}{ MEDIAN_INFO } & \#SEQ & \multicolumn{3}{|c|}{ dbSNP_ID } \\
\hline 0.0 & \multicolumn{2}{|c|}{ Damaging } & & 3.58 & 380 & & & \\
\hline
\end{tabular}

E
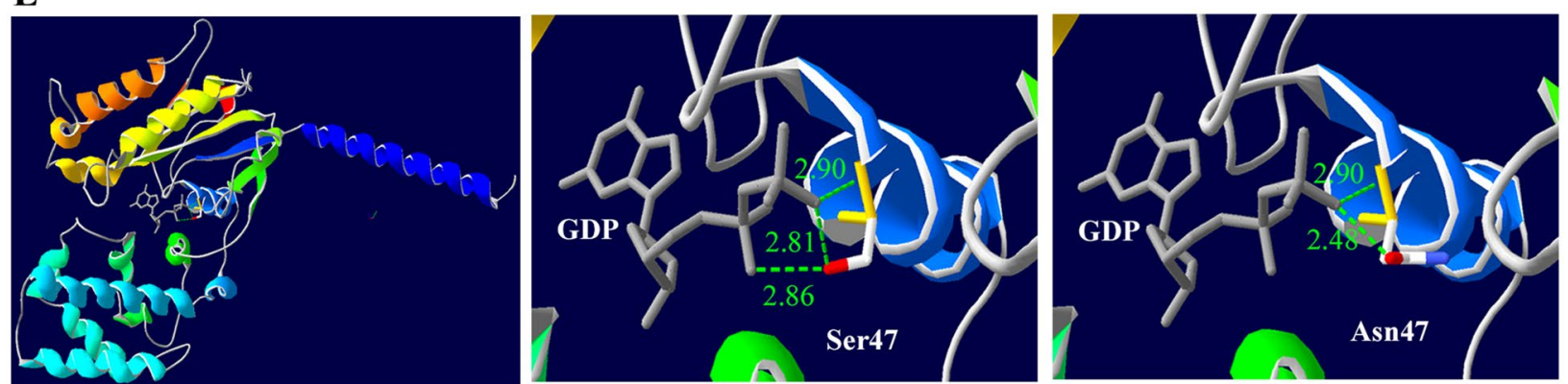

$\mathbf{F}$

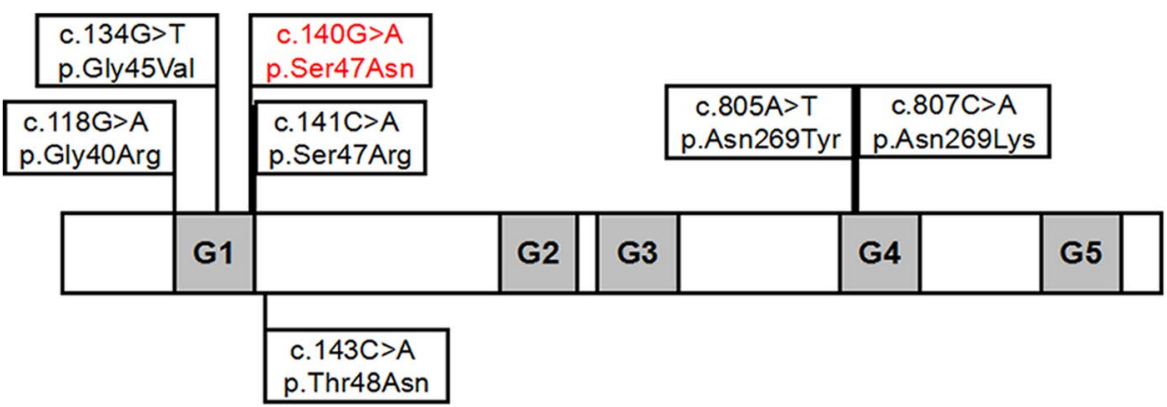

Fig. 2 A Whole exome sequencing of the GNA/3 heterozygous C.140G > A variant (indicated in a red box). B Sanger sequencing of the GNA/3 heterozygous C.140G > A variant (indicated by a red arrow). C Evaluation of the amino acid conservation by Ugene. Each residue in alignment is assigned a color according to the ClustalX color scheme. The Ser47 of Gai3 (indicated in a red box) is highly conserved accross various species. D In silico prediction of the GNAI3 c.140G > A variant by PolyPhen, MutationTaster, PROVEAN, and SIFT. EThe three dimensional molecular structure of Gai3 and the guanosine diphosphate (GDP) ligand by SWISS-MODEL and Swiss-PdbViewer. The overview (left panel) and magnified views of the wild-type Ser47 (middle panel) and mutant Asn47 (right panel) are shown accordingly. The H-bonds to GDP are shown as green dashed lines, with $\mathrm{H}$-bond distances ( $\AA$ ) shown in green numbers. F Schematic representation of all the identified mutations in the GNA/3 gene (NM_0064). Five guanine nucleotide-binding sites (G1-G5) are indicated by gray boxes. The novel missense mutation in the present report is shown in red 
Table 1 Clinical features of reported auriculocondylar syndrome (ACS) cases with GNAI3 (NM_0064) mutations

\begin{tabular}{|c|c|c|c|c|c|c|c|c|c|}
\hline \multirow[b]{2}{*}{ Publications } & \multicolumn{2}{|l|}{$\begin{array}{l}\text { c.118G >C } \\
\text { p.Gly40Arg }\end{array}$} & \multirow{2}{*}{$\begin{array}{l}\text { c.134G > T } \\
\text { p.Gly45Val } \\
\text { Propst } \\
2013 ; \\
\text { Romanelli } \\
\text { Tavares } \\
2015 \text { (SP1) }\end{array}$} & \multirow{2}{*}{$\begin{array}{l}\text { c.140G > A } \\
\text { p.Ser47Asn } \\
\text { This study }\end{array}$} & \multirow{2}{*}{$\begin{array}{l}\text { c. } 141 C>A \\
\text { p.Ser47Arg } \\
\text { Gordon } \\
2013 \text { (Case } \\
7 \text { ) }\end{array}$} & \multirow{2}{*}{$\begin{array}{l}\text { c. } 143 \text { C > A } \\
\text { p.The48Asn } \\
\text { Tavares } \\
2015 \text { (SP2) }\end{array}$} & \multirow{2}{*}{$\begin{array}{l}\text { c.805A > T } \\
\text { p.Asn269Tyr } \\
\text { Guion- } \\
\text { Almeida } \\
2002 \text { (Patient } \\
\text { 1); Masotti } \\
\text { 2008 (F2); } \\
\text { Romanelli } \\
\text { Tavares } 2015 \\
\text { (ACS1) }\end{array}$} & \multirow{2}{*}{$\begin{array}{l}\text { c.807C > A } \\
\text { p.Asn269Lys } \\
\text { Yanagi } 2021\end{array}$} & \multirow[t]{2}{*}{ Summary } \\
\hline & $\begin{array}{l}\text { Rieder } \\
2012 \text { (S008) }\end{array}$ & $\begin{array}{l}\text { Erlich 2000; } \\
\text { Rieder } \\
2012 \text { (S011) }\end{array}$ & & & & & & & \\
\hline $\begin{array}{l}\text { Familial/spo- } \\
\text { radic }\end{array}$ & Familial & Familial & Sporadic & Sporadic & Familial & Sporadic & Familial & Sporadic & $1: 1$ \\
\hline $\begin{array}{l}\text { Individuals } \\
\text { with mutation }\end{array}$ & $2(1 \mathrm{~F} ; 1 \mathrm{M})$ & $2(2 F, 0 M)$ & $1(\mathrm{M})$ & $1(\mathrm{~F})$ & $2(1 F, 1 M)$ & $1(\mathrm{M})$ & $9(4 F, 5 M)$ & $1(F)$ & $19(10 \mathrm{~F}, 9 \mathrm{M})$ \\
\hline $\begin{array}{l}\text { Penetrant } \\
\text { patients }\end{array}$ & $1 / 2$ & $2 / 2$ & $1 / 1$ & $1 / 1$ & $2 / 2$ & $1 / 1$ & $8 / 9$ & $1 / 1$ & $\begin{array}{l}17 / 19 \\
(89.47 \%)\end{array}$ \\
\hline Proband sex & $\mathrm{F}$ & $\mathrm{F}$ & M & $\mathrm{F}$ & $\mathrm{F}$ & M & $\mathrm{F}$ & $\mathrm{F}$ & $8(6 F, 2 M)$ \\
\hline \multicolumn{10}{|l|}{ MANDIBLE } \\
\hline $\begin{array}{l}\text { Microg- } \\
\text { nathia }\end{array}$ & $1 / 2$ & $2 / 2$ & $1 / 1$ & $1 / 1$ & $2 / 2$ & $1 / 1$ & $6 / 9$ & $1 / 1$ & $\begin{array}{l}15 / 19 \\
(78.95 \%)\end{array}$ \\
\hline $\begin{array}{r}\text { Condyle } \\
\text { hypoplasia }\end{array}$ & $1 / 2$ & $2 / 2$ & $1 * / 1$ & $1 / 1$ & $2 * / 2$ & $1 * / 1$ & $2 / 9$ & $1 / 1$ & $\begin{array}{l}11 / 19 \\
(57.89 \%)\end{array}$ \\
\hline \multicolumn{10}{|l|}{ EAR } \\
\hline $\begin{array}{c}\text { Auricular } \\
\text { malformation }\end{array}$ & $1 / 2$ & $2 / 2$ & $1 * / 1$ & $0 / 1$ & $1 \# / 2$ & $1 \# / 1$ & $6 / 9$ & $1 / 1$ & $\begin{array}{l}13 / 19 \\
(68.42 \%)\end{array}$ \\
\hline $\begin{array}{l}\text { Hearing } \\
\text { loss }\end{array}$ & NA & $2 / 2$ & $1 / 1$ & NA & $0 / 2$ & $1 / 1$ & $2 / 9$ & $1 / 1$ & $7 / 16$ (43.75\%) \\
\hline \multicolumn{10}{|l|}{ MOUTH } \\
\hline $\begin{array}{l}\text { Microsto- } \\
\text { mia }\end{array}$ & $1 / 2$ & $2 / 2$ & $1 / 1$ & NA & $2 / 2$ & $1 / 1$ & $4 / 9$ & $1 / 1$ & $\begin{array}{l}12 / 18 \\
(66.67 \%)\end{array}$ \\
\hline $\begin{array}{l}\text { Glossop- } \\
\text { tosis }\end{array}$ & $1 / 2$ & $2 / 2$ & $1 / 1$ & NA & $0 / 2$ & $1 / 1$ & $2 / 9$ & $1 / 1$ & 8/18 (44.44\%) \\
\hline $\begin{array}{l}\text { Abnormal } \\
\text { palate }\end{array}$ & NA & $2 / 2$ & $1^{a} / 1$ & NA & $0 / 2$ & $1 \% / 1$ & $1 / 8$ & $0 / 1$ & 5/15 (33.33\%) \\
\hline \multicolumn{10}{|l|}{ FACE } \\
\hline $\begin{array}{l}\text { Prominent } \\
\text { cheeks }\end{array}$ & $1 / 2$ & $2 / 2$ & $1 / 1$ & $1 / 1$ & $2 / 2$ & $1 / 1$ & $3 / 9$ & $1 / 1$ & $\begin{array}{l}12 / 19 \\
(63.16 \%)\end{array}$ \\
\hline $\begin{array}{l}\text { Round } \\
\text { faces }\end{array}$ & $1 / 2$ & $2 / 2$ & $1 / 1$ & $1 / 1$ & $2 / 2$ & $1 / 1$ & $2 / 9$ & $1 / 1$ & $\begin{array}{l}11 / 19 \\
(57.89 \%)\end{array}$ \\
\hline Asymmetry & $0 / 2$ & $0 / 2$ & $0 / 1$ & $0 / 1$ & $2 * / 2$ & $1 * / 1$ & $0 / 9$ & $0 / 1$ & $3 / 19$ (15.79\%) \\
\hline \multicolumn{10}{|l|}{ OTHER } \\
\hline $\begin{array}{l}\text { Respiratory } \\
\text { distress }\end{array}$ & $1^{\& / 2}$ & $2^{\& / 2}$ & $1 / 1$ & NA & NA & $1 / 1$ & $2^{8 / 9}$ & $1 \% / 1$ & $8 / 16(50 \%)$ \\
\hline $\begin{array}{r}\text { Feeding } \\
\text { difficulties }\end{array}$ & $1^{\&} / 2$ & $2^{8 / 2}$ & $1 / 1$ & NA & NA & $1 / 1$ & $18 / 9$ & $1 \& / 1$ & $7 / 16(43.75 \%)$ \\
\hline \multicolumn{10}{|l|}{ PRENATAL $\$$} \\
\hline $\begin{array}{l}\text { Polyhy- } \\
\text { dramnios }\end{array}$ & NA & $1 / 1$ & NA & $1 / 1$ & NA & NA & $1 / 1$ & NA & $3 / 3(100 \%)$ \\
\hline $\begin{array}{l}\text { Microg- } \\
\text { nathia }\end{array}$ & NA & $1 / 1$ & NA & $1 / 1$ & NA & NA & $0 / 1$ & NA & 2/3 (66.67\%) \\
\hline
\end{tabular}

Abbreviations: $M$ male; $F$ female; $N A$ not reported

*: More severe on the right; \#: right ear only; \&: severe cases with tracheostomy or gastrostomy; \$: evaluated only in the proband; a: high-arched palate; b: bifid uvula

glossoptosis or tongue/soft-tissue abnormalities. The fetal stomach bubble was not small in our fetus with dysphagia. Prenatal auricle defects have been reported together with multiple deformities in other syndromes of the first and second pharyngeal arches $[19,20]$. In the two reports of ACS patients (QME positive) with brief 
prenatal descriptions, ear abnormalities were not mentioned $[12,14]$. The ears of our fetus were low-set, but unexpectedly not in accord with the characteristic QME. The face was round and symmetrical, with prominent cheeks which might be easily overlooked. Collectively, severe hypoplastic mandible and the accompanying polyhydramnios could be considered as prenatal indicators of ACS.

ACS is genetically heterogeneous with pathogenic variants identified in the GNAI3, PLCB4, and EDN1 genes. They encode signaling molecules in the EDN1-EDNRA pathway, which is important for patterning the mandibular portion of the first pharyngeal arch $[2,5]$. Gai3 forms the heterotrimeric $G$ protein with $G \beta y$ to transduct the EDN1-EDNRA signal to PLC, which induces the expression of transcription factors DLX5 and DLX6 required for the differentiation of neural crest cells [2]. All the currently known GNAI3 mutations were autosomal-dominant and missense, and structurally resided in the G1 and G4 boxes involved in binding guanine nucleotides [3, $4,7,8]$. The fetus in this report carried a novel de novo p.Ser47Asn mutation in the conserved G1 box. A dominant negative effect of ACS-associated mutant Goi3 has been proposed in that the mutant proteins were capable of EDNRA coupling but defective in guanosine binding using an in vitro Xenopus model [6]. The substitution of Ser47 into Asn47 was predicted to be deleterious as it disrupted one of the three H-bonds toward GDP, which might thereafter disrupt the EDN1-EDNRA signaling pathway.

A wide range of phenotypic variability and incomplete penetrance have been observed in ACS [3, 4]. We summarized the clinical features of all identified ACS cases with GNAI3 gene mutations including ours, showing a penetrance of $89.47 \%$. Overall, the most common features included micrognathia, auricular malformation, microstomia, prominent cheeks, mandibular hypoplasia, and round faces. Further, there were two interesting observations in GNAI3-related ACS: severe cases were female-dominated and deformities were right-side-prone. More cases are needed to clarify these trends, and more functional experiments are needed to elucidate possible explanations. QME is the characteristic auricular malformation in ACS, with severity varying from complete cleft to a mild notching between the helix and lobule. Our fetus with the p.Ser47Asn mutation showed normal ears. A previous familial case with p.Ser47Arg mutation showed completely normal ears in the father and a only right ear constriction in the daughter [4]. In addition, a boy with p.The48Asn showed only right-side QME [3]. These cases might infer a mild ear phenotype by GNAI3 mutations at the G1 boundary of Ser47 and The48. In comparison to the mandibular phenotype, our fetus with p.Ser47Asn mutation was more severe than the patients with p.Ser47Arg mutation [4]; and the patient carrying p.Asn269Lys mutation was also more severe than the patients carrying p.Asn269Tyr mutation [8, 14]. A possible explanation might be that the substitution to different amino acids at the same position destruct the GDP binding at different degrees: Arg47 holds three H-bonds to GDP compared to two by Asn47 (analyzed by Swiss-PdbViewer, data not shown); and the hydrophobic interaction might be easily disrupted by Lys 269 than Tyr269 [8].

In conclusion, severe micrognathia and mandibular hypoplasia accompanied by polyhydramnios are prenatal indicators of ACS. A novel missense variant of GNAI3 was identified in the G1 box to impair the guanine nucleotide-binding function. The phenotypic parameters of all previous ACS cases with GNAI3 gene mutations were summarized to improve awareness of this rare disorder.

\section{Abbreviations \\ ACS: Auriculocondylar syndrome; QME: Question mark ear; GNAI3: Guanine nucleotide binding protein alpha-inhibiting activity polypeptide 3; PLCB4: Phospholipase C beta 4; EDN1: Endothelin 1; EDNRA: Endothelin type A recep- tor; AFI: Amniotic fluid index; SDP: Single deepest pocket; WES: Whole exome sequencing; GDP: Guanosine diphosphate.}

\section{Acknowledgements}

We would like to thank the individuals who participated in this study.

\section{Authors' contributions}

$Y Z$ and $X L$ designed the research. WS performed the ultrasonic examination and interpreted the results. JW performed amniocentesis and provided genetic counseling. GC and RH performed the genetic analysis. BZ reviewed literature. XL drafted the manuscript. YZ revised the manuscript. All authors approved the final version, and are willing to take public responsibility for the accuracy and integrity of its content.

\section{Funding}

This study was supported by grant from National Key Technologies R\&D Program of China (2016YFC1000702) for clinical data collection, New Medical Technology and Project of China Medical University (112-3110210717) for genetic analysis and Doctoral Start-up Foundation of Liaoning Province (2019BS-274) for language editing.

Availability of data and materials

The datasets obtained and/or analyzed during the current study are available from the corresponding author on reasonable request.

\section{Declarations}

\section{Ethics approval and consent to participate}

The study was conducted in accordance with the Helsinki Declaration and approved by the Ethics Committee of Shengjing Hospital of China Medical University (2021PS535K). Written informed consent was obtained from the participants.

\section{Consent for publication}

Written informed consent was obtained from the participants, and we confirm that the patients gave consent for their personal or clinical details along with any identifying images to be published in this study. Documentation of the written consent will be provided to the journal upon request. 


\section{Competing interests}

The authors declare that they have no competing interests.

\section{Author details}

'Department of Clinical Genetics, Shengjing Hospital of China Medical University, Shenyang, China. ${ }^{2}$ Department of Ultrasonography, Shengjing Hospital of China Medical University, Shenyang, China. ${ }^{3}$ Department of Obstetrics and Gynecology, Shengjing Hospital of China Medical University, Shenyang, China.

Received: 5 August 2021 Accepted: 28 October 2021

Published online: 17 November 2021

\section{References}

1. Passos-Bueno MR, Ornelas CC, Fanganiello RD. Syndromes of the first and second pharyngeal arches: a review. Am J Med Genet A. 2009;149A(8):1853-9. https://doi.org/10.1002/ajmg.a.32950.

2. Clouthier DE, Passos-Bueno MR, Tavares AL, Lyonnet S, Amiel J, Gordon CT. Understanding the basis of auriculocondylar syndrome: insights from human, mouse and zebrafish genetic studies. Am J Med Genet C Semin Med Genet. 2013;163C(4):306-17 https://doi.org/10.1002/ajmg.c.31376.

3. Romanelli Tavares VL, Gordon CT, Zechi-Ceide RM, Kokitsu-Nakata NM, Voisin N, Tan TY, et al. Novel variants in GNAI3 associated with auriculocondylar syndrome strengthen a common dominant negative effect. Eur J Hum Genet. 2015;23(4):481-5 https://doi.org/10.1038/ejhg.2014.132.

4. Gordon CT, Vuillot A, Marlin S, Gerkes E, Henderson A, AlKindy A, et al. Heterogeneity of mutational mechanisms and modes of inheritance in auriculocondylar syndrome. J Med Genet. 2013;50(3):174-86 https://doi. org/10.1136/jmedgenet-2012-101331.

5. Gordon CT, Petit F, Kroisel PM, Jakobsen L, Zechi-Ceide RM, Oufadem $M$, et al. Mutations in endothelin 1 cause recessive auriculocondylar syndrome and dominant isolated question-mark ears. Am J Hum Genet. 2013:93(6):1118-25 https://doi.org/10.1016/j.ajhg.2013.10.023.

6. Marivin A, Leyme A, Parag-Sharma K, DiGiacomo V, Cheung AY, Nguyen $\mathrm{LT}$, et al. Dominant-negative Ga subunits are a mechanism of dysregulated heterotrimeric $\mathrm{G}$ protein signaling in human disease. Sci Signal. 2016;9(423):ra37. https://doi.org/10.1126/scisignal.aad2429.

7. Rieder MJ, Green GE, Park SS, Stamper BD, Gordon CT, Johnson JM, et al. A human homeotic transformation resulting from mutations in PLCB4 and GNAl3 causes auriculocondylar syndrome. Am J Hum Genet. 2012;90(5):907-14 https://doi.org/10.1016/j.ajhg.2012.04.002.

8. Yanagi K, Morimoto N, Iso M, Abe Y, Okamura K, Nakamura T, et al. A novel missense variant of the GNAI3 gene and recognisable morphological characteristics of the mandibula in ARCND1. J Hum Genet. 2021 Epub ahead of print https://doi.org/10.1038/s10038-021-00915-z.
9. Moore TR, Cayle JE. The amniotic fluid index in normal human pregnancy. Am J Obstet Gynecol. 1990;162(5):1168-73 https://doi.org/10.1016/00029378(90)90009-v.

10. Neuschulz J, Wilhelm L, Christ H, Braumann B. Prenatal indices for mandibular retrognathia/micrognathia. J Orofac Orthop. 2015;76(1):30-40 https://doi.org/10.1007/s00056-014-0257-1.

11. Kepkep K, Tuncay YA, Göynümer G, Yetim G. Nomogram of the fetal gastric size development in normal pregnancy. J Perinat Med. 2005;33(4):336-9 https://doi.org/10.1515/jpm.2005.060.

12. Erlich MS, Cunningham ML, Hudgins L. Transmission of the dysgnathia complex from mother to daughter. Am J Med Genet. 2000;95(3):269-74.

13. Propst EJ, Ngan BY, Mount RJ, Martin-Munoz D, Blaser S, Harrison $\mathrm{RV}$, et al. Ossicular fusion and cholesteatoma in auriculo-condylar syndrome: in vivo evidence of arrest of embryogenesis. Laryngoscope. 2013;123(2):528-32 https://doi.org/10.1002/lary.23492.

14. Guion-Almeida ML, Zechi-Ceide RM, Vendramini S, Kokitsu-Nakata NM. Auriculo-condylar syndrome: additional patients. Am J Med Genet. 2002;112(2):209-14 https://doi.org/10.1002/ajmg.10631.

15. Masotti C, Oliveira KG, Poerner F, Splendore A, Souza J, Freitas Rda S, et al. Auriculo-condylar syndrome: mapping of a first locus and evidence for genetic heterogeneity. Eur J Hum Genet. 2008;16(2):145-52 https://doi. org/10.1038/sj.ejhg.5201955.

16. Jampol M, Repetto G, Keith DA, Curtin H, Remensynder J, Holmes LB. New syndrome? Prominent, constricted ears with malformed condyle of the mandible. Am J Med Genet. 1998;75(5):449-52 https://doi.org/10. 1002/(sici)1096-8628(19980217)75:5\%3C449::aid-ajmg1\%3E3.0.co;2-i.

17. Teoh M, Meagher S. First-trimester diagnosis of micrognathia as a presentation of Pierre Robin syndrome. Ultrasound Obstet Gynecol. 2003;21(6):616-8 https://doi.org/10.1002/uog.141.

18. Lu J, Sahota DS, Poon LC, Ting YH, Cheng YKY, Wang Y, et al. Objective assessment of the fetal facial profile at second and third trimester of pregnancy. Prenat Diagn. 2019;39(2):107-15 https://doi.org/10.1002/pd. 5371.

19. Liu J, Lin P, Pang J, Jia Z, Peng $Y, X i H$, et al. Identification of a novel gross deletion of TCOF1 in a Chinese prenatal case with Treacher Collins syndrome. Mol Genet Genomic Med. 2020;8(8):e1313 https://doi.org/10. 1002/mgg3.1313.

20. Song QY, Luo H. Ultrasound diagnosis of oculo-auriculo-vertebral spectrum in a mid-trimester foetus. Prenat Diagn. 2021;41(6):791-2 https:// doi.org/10.1002/pd.5936.

\section{Publisher's Note}

Springer Nature remains neutral with regard to jurisdictional claims in published maps and institutional affiliations.
Ready to submit your research? Choose BMC and benefit from:

- fast, convenient online submission

- thorough peer review by experienced researchers in your field

- rapid publication on acceptance

- support for research data, including large and complex data types

- gold Open Access which fosters wider collaboration and increased citations

- maximum visibility for your research: over $100 \mathrm{M}$ website views per year

At $\mathrm{BMC}$, research is always in progress.

Learn more biomedcentral.com/submissions 